\title{
Touring in Kent: Some Observations from Records Published to Date
}

\begin{abstract}
To date, published dramatic records from England reveal that County Kent saw more touring activity than any other English county. Some reasons for this activity include Kent's local, pre-Reformation drama, its several towns as playing venues, and political and economic factors.
\end{abstract}

Using the volumes of the University of Toronto's Records of Early English Drama (REED) printed to date, augmented by other printed sources, this essay argues that during the late medieval and early modern eras County Kent was the most favored area in England to be visited by touring entertainers. ${ }^{1}$ This finding holds true even though the published REED: Kent volume only covers the diocese of Canterbury. The records from the diocese of Rochester are yet to be published and should yield yet more data.

My focus, I must stress, is upon geographic locales - county and town rather than specific venues within those locales. As noted below, for instance, King Edward I's players performed in Canterbury, Kent at Christ Church Priory. Several records note, or suggest, that performances were in a town's guildhall, for example Booth Hall in Shrewsbury, or at aristocratic holdings, like Skipton Castle in Yorkshire. And as John M. Wasson notes, the residences of local aristocrats often housed travelling entertainers, who probably performed there as well. ${ }^{2}$

Dramatic records published to date come from a variety of sources: town records, ecclesial establishments, church wardens' accounts, household records, sometimes court proceedings. Such records yield evidence of 2,200 performances in Kent — by touring royal and aristocratic players, minstrels, musicians, and other entertainers - between 1277, when the 'ystronibus' of King Edward I received twelve pence at Christ Church Priory, Canterbury, and 1641, when the players of the prince of Wales (later King Charles II) were dismissed from Canterbury with

James H. Forse (jhforse60@hotmail.com) is professor of history and adjunct professor of theatre, emeritus, at Bowling Green State University. 
a payment of $£ 1$. Including unnamed troupes and touring players from various towns, the number increases to about $2,475 .{ }^{3}$ Other counties cannot even come close to that number of appearances. For purposes of an admittedly imprecise sense of comparison I use four other counties: Devon, Shropshire, Sussex, and York. Each of these counties hosted visiting entertainers over 400 times between the 1300s and 1642, and the counties represent varying geographic areas: Devon in the southwest, Shropshire in the west on the Welsh border, Sussex in the southeast bordering Kent, and York in the north. Sussex, perhaps, benefited from its proximity to Kent, and the fact that Rye, which saw the most performances, was a member of the confederation of the Cinque Ports. County Warwick is only other county approaching those numbers. To date, the vast majority of data is from Coventry, supplemented by a few citations in other sources naming a few other locations - Caludon and Clinton Castles, Maxstoke Priory, Stratford-uponAvon, and Warwick town. Very few records date before the late 1500s, however, making meaningful comparisons to Kent problematic. ${ }^{4}$

Although Devon had become an oft-visited destination for touring entertainers by the mid-1400s, ${ }^{5}$ Devon comes in a distant second to Kent. Devon's records mention over 650 instances of visiting performers, beginning with those of Prince Edward of Woodstock (the 'Black Prince') at Exeter in 1361 and ending with King Charles's trumpeters in Dartmouth in $1634 .{ }^{6}$ Sussex, with about 435 entries between 1346, when entertainers of King Edward III performed at Battle Abbey, and 1642, when players of Mr Herbert Morley performed at Chichester, comes in third. ${ }^{7}$ Shropshire's records list around 400 appearances of visiting performers between 1338 and $1642 ;^{8}$ and York's records show 411 appearances by visiting performers between 1323 and 1642. ${ }^{9}$ These numbers, and those given below in comparisons, exclude visits by unnamed performers and troupes identified as players from various towns.

We might also compare prominent towns from each of the five counties for which there are extensive dramatic records over similar stretches of time. Here, too, County Kent leads the others. Dover was one of Kent's 'premier' towns. In the mid-1500s its permanent population was about 1,700 , growing to 3,000 by 1600. Dover's population also grew thanks to temporary inhabitants, since the town was the county's principal port and maritime trade was an important part of its economy. Dover also was the administrative centre for the lord wardens of Cinque Ports, and Dover Castle was strategic to defending the coast. ${ }^{10}$ Given that status, unsurprisingly, Dover's dramatic records between 1387 and 1625 include over 600 instances of performances by royal and aristocratic entertainers. ${ }^{11}$ 
Exeter, with a population of over 2,000, was the chief city for not only Devon but also Dorset and Cornwall. An episcopal city, it also served the crown as an administrative centre, and was a busy market town, a hub for Devon's woolen trade. ${ }^{12}$ Sally-Beth MacLean calls Exeter the 'provincial capital of the southwest', noting that the city also was a hub for major roads leading south to Dartmoor and Plymouth, west to Cornwall, and north to Bristol, running along the boundaries of the Welsh Marches to Gloucester, Worcester, and Shrewsbury. ${ }^{13}$ No wonder it was a preferred locale for entertainers touring in Devon. Exeter's dramatic records from 1339 to 1623 reveal over 340 performances by travelling entertainers, ${ }^{14}$ just a tad over half of those for Dover. Shrewsbury, only nine miles from the Welsh border, was the centre for royal government in Shropshire and the adjoining Welsh counties. A busy market town with a major castle and a population of perhaps 2,000, it also housed an important pilgrimage site: the shrine of St Winifred at St Peter's monastery. ${ }^{15}$ From 1338 to 1642 Shrewsbury's accounts list a bit over 300 performances by touring entertainers, ${ }^{16}$ like Exeter around half the amount for Dover for a similar stretch of time. Rye was, perhaps, the most prominent town in Sussex. Like Dover, Rye was an important port and market town, a member of the Cinque Ports, with the same charters and liberties, and also housed an important coastal defensive structure, Camber Castle. It had access to roads to London. ${ }^{17}$ From 1449 to 1616 Rye's dramatic records yield 460 performances by travelling entertainers, a substantial number, but still only $75 \%$ of Dover's numbers. ${ }^{18}$ York, the seat of England's only other archbishop, and England's chief fortification in the north, was the most important economic, religious, governmental, and commercial center in the north. Its chartered status gave it substantial independence, and its guilds' records demonstrate the city's economic prosperity. Its prominence during the Wars of the Roses demonstrates its political importance within the realm. ${ }^{19}$ York's dramatic records dating from 1395 to 1642 list 340 performances in the city by visiting entertainers, ${ }^{20}$ a little over half the number appearing in Dover's records. Even Kent's New Romney, nowhere near the population or importance of Exeter, Shrewsbury, Rye, and York, approaches them in number of visiting performers. Its dramatic records from 1387 to 1624 list over 240 such appearances. ${ }^{21}$

Perhaps Kent offered more opportunities for performers than other counties. Kent was more densely populated, with a population of around 80,000 in 1550, and possessed more prosperous chartered towns and semi-independent liberties than most other English counties. Around twenty-five towns had populations of over 400 inhabitants, while some communities were larger, such as Canterbury with around 3,000, Maidstone with approximately 2,400, Dover with perhaps 
1,700 , and Sandwich with about 1,600. The county was known for its comparative wealth and relatively prosperous citizens. Probate records reveal many even at the level of yeomen leaving estates valued in hundreds of pounds. Its economy was diverse. Farming there had become fairly commercial, with grain, wool, hides, and other commodities being sent off to London. Kent's industries included cloth making, iron foundries, papermaking, leather making, shipbuilding, and fishing, as well as shipping of goods to the Baltic and the Low Countries. ${ }^{22}$

Kent also seems to have had a taste for drama. Although most pre-Reformation English counties had long traditions of local religious drama as well more secular entertainments like Robin Hood games, Kent's dramatic records reveal extensive touring of entertainments by Kentish towns to other locales. From 1387 to 1547 Kentish dramatic records from several towns list 200 payments to visiting players from other towns. In particular, Faversham, Hythe, Lydd, and New Romney often toured their respective productions amongst one another. All told, twentyfour Kentish towns at one time or another sent their players to perform elsewhere within the county. ${ }^{23}$ Even the small town of Appledore, with a population of around 250, toured its play to Lydd and New Romney in 1457, 1488, 1516, and 1517. ${ }^{24}$ Some Kentish towns sent their performances to other counties, sixteen in all, and as far away as Cornwall, Shropshire, Lancashire, and Lincoln. ${ }^{25}$ And Kentish towns also hosted performances sent there from towns in eleven other counties, including as far away as Northumberland, York, and Durham. ${ }^{26}$

Counties Devon, Shropshire, Sussex, and York (used here for comparison) experienced less touring of town players to neighbouring communities. Devon's records list sixty-two such performances. Only nine were from Devonshire communities; the rest came from other nearby counties — with the exceptions of three from Kentish towns, one from London, and one from York. ${ }^{27}$ Shropshire's records show eighteen performances by visiting community players. Five Shropshire towns are represented. The others came from the neighboring counties of Gloucester, Cheshire, Hereford, and Worcester, except for a few performances by players from Nottingham and Kent. The majority of these visiting town players performed in Shrewsbury. ${ }^{28}$ Sussex saw eighty-seven performances by town players on tour, but only seven Sussex towns are represented. Although towns from twelve other counties performed in Sussex, forty-eight (55\%) of those visiting town troupes came from Kent. The vast number of these performances were in Rye. ${ }^{29}$ Yorkshire's records reveal twenty-one performances by visiting town players, but only six were Yorkshire towns. The rest were by troupes from counties far afield, including one from Wales. ${ }^{30}$ Notably, touring players from Kentish towns appear not only in the records of each of these four counties, but also, as noted 
above, in records from sixteen other counties. In dramatic records published to date Kentish towns toured out of county more often than those from any other county.

We get a glimpse at what was involved in staging a more elaborate town's play from New Romney's attempts to revive its passion play after plays and the like had been banned in the reign of Edward VI. Records from 1555 indicate the town's intention to mount the play. The dramatis personae includes Herod, Herod's Knight, Herod's messenger, Tormentors, Pilate, Pilate's messenger, Caiphas's messenger, the Virgin, Doctor, Marye, Simeon, and devils. Players received their respective 'speeches or ptes in theseyd playe' and were ordered to attend rehearsals 'wthowten eny collusion (god the kynge and queens maties, and no Reasonable cause lettyng)', with the expectation that they would learn their parts before Pentecost. The town assigned various tasks in what we would call 'technical' aspects of the production to sixty-two other people, and prescribed fines for those who did not carry out their assigned tasks. These arrangements, for a town of no more than 1,000 people, indicate a high level of community involvement. ${ }^{31}$ We lack records of expenses or income for the play in 1555, and apparently it was not performed. Expenditures from 1560 reveal another attempt at revival. Costs for costumes, set pieces, scriveners' copies, bann criers, beer, and food totaled a whopping 11,985 pence $^{32}$ - enough money at that time to buy almost 4,000 chickens, or 2,000 pigs, or thirty-three cows, or pay the salary of the schoolmaster at Cratfield (Suffolk) for twenty-five years. ${ }^{33}$ Despite contributions towards the costs by the towns of Ivychurch and Lydd, and 2,400 pence from a certain 'Iohn fforcett', the income from the play in 1560 was only 6,785 pence, a loss of over 2,500 pence. And if this were the play New Romney toured to Dover in 1561, the players only received 24 pence. ${ }^{34}$ That loss, along with Elizabeth I's return to the proscriptions of the church of Edward VI, helps explain why there are no further records of the play's performances.

Dramatic records from twenty Kentish towns - Boxley, Canterbury, Chartham, Dover, Eastry, Eltham, Faversham, Folkstone, Fordwich, Gravesend, Hecington, Hythe, Ickham Ipswich, Isle of Sheppy, Lydd, Maidstone, New Romney, Rochesester, and Sandwich ${ }^{35}$ - note performances by visiting entertainers patronized by royalty, peers, and knights. Records from Canterbury, Dover, Faversham, Hythe, Lydd, New Romney, and Sandwich contain one hundred or more performances. In the pre-Reformation era these towns had been the most active ones to send their plays on tour.

In contrast, though Devon has dramatic records from nine towns - Ashburton, Barnstaple, Grounton, Dartmouth, Exeter, Honton, Plymouth, Tavistock, 
and Tiverton ${ }^{36}$ - the majority of patronized entertainers played at three locations: Barnstaple, Exeter, and Plymouth. Shropshire's records list performances in seven towns - Blackmere, Bridgnorth, Claverly, Ludlow, Shrewsbury, Wellington, and Worfield ${ }^{37}$ — but the overwhelming number of performances were at Shrewsbury. Sussex dramatic records list performances in seven locations Battle, Chichester, Kewes, Lewes, Ramsbury, Robertsbridge, and Rye ${ }^{38}$ — and reveal a similar pattern; the vast majority of appearances occurred in Rye. Records from Yorkshire follow the same pattern. Sources to date show ten locales - Beverley, Hedon, Hull, Doncaster, Cowick, Masham, Selby and Fountains Abbeys, Skipton Castle, and York ${ }^{39}$ - but the vast majority of performances were in the city of York. When the Yorkshire volumes for East Riding, West Riding, and North Riding are published we will have more data, but thus far, the fewer number of appearances in what were the major municipalities in Devon, Shropshire, Sussex, and Yorkshire suggests there were few, if any, appearances in smaller towns in those counties. So, it seems that County Kent - which unlike Devon, Shropshire, Sussex, and Yorkshire did not have a single, dominant municipality — offered travelling entertainers far more opportunity than other counties to perform and earn money in several localities, all within short distances from one another.

To illustrate these points I proffer, as examples, the tours of entertainers attached to four patrons whose entertainers toured widely. For each patron I assign a particular year and detail their entertainers' performances in Kent, Devon, Sussex, Shropshire, and York. Three of the four examples come from the era of Elizabeth I, since touring peaked during her reign. ${ }^{40}$ In 1589 Queen Elizabeth's Men performed eighteen times in Kent (once in Rochester, twice in Canterbury, Dover, Faversham, Folkstone, Lydd, Maidstone, and New Romney, and thrice in Hythe). That same year they performed once in Devon (Exeter) and twice in Sussex (Rye). Her troupe did not perform that year in Shropshire or York. ${ }^{41}$ The players of her favourite, Robert Dudley, earl of Leicester, performed in Kent six times in 1569 (Canterbury, Dover, Faversham, Lydd, and New Romney). In Devon they appeared five times (twice in Plymouth, twice in Totnes, and once in Dartmouth). In Sussex they played once (Rye), and they did not play in Shropshire or York. ${ }^{42}$ The players of Elizabeth's later favourite, Robert Devereux earl of Essex, played Kent seven times in 1589 (Dover, twice in Faversham, Hythe, Lydd, Maidstone, and New Romney). They played once in Sussex (Rye), and in the city of York. Essex's players did not go to Devon or Shropshire. ${ }^{43}$ Moving back in time for the fourth example, entertainers patronized by Elizabeth's father (Henry VIII) appear in Kentish records five times in 1540 (Canterbury, Dover, Faversham, 
Lydd, New Romney). They appeared only once in Devon (Exeter), three times in Shropshire (Shrewsbury), once in Sussex (Rye), and once in York. ${ }^{44}$

Let us compare overall recompenses for each of these patrons' entertainers in the years given above. From Kent, from the eight towns in which they played in 1589, Queen Elizabeth's Men received a total of 3,016 pence (sums are in pence for ease in calculation). From Exeter in Devon they received 308 pence, from Ludlow in Shropshire 120 pence, and from Rye in Sussex 480 pence, for a total of 908 pence from three counties. The Queen's Men did not play in York. Hence, out of a total income of 3,924 pence from those four counties, almost $76 \%$ came from Kent. In 1569 Leicester's players did not play in Shropshire and York, but received a total of 546 pence from five Kentish towns. His players received a bit more, 684 pence from three towns in Devon, and from Rye in Sussex they received 120 pence, for a total of 1,400 pence from those three counties. Though receiving less from Kent than from Devon, Kent still accounts for $42.5 \%$ of the total. Essex's players garnered a total of 420 pence from six towns in Kent in 1589. They received 240 pence from Rye in Sussex and 360 pence from York; they did not perform in Devon or Shropshire. Essex's players garnered a total 1,020 pence from four counties. Hence $41 \%$ of that income came from Kent.

The entertainers of Henry VIII earned 372 pence from five Kentish towns in 1540, 160 pence from Exeter in Devon, 155 pence from three performances in Shrewsbury in Shropshire, 180 pence from Rye in Sussex. The York records are a bit confusing. First appears 'Rewards to the kynges players and oyer honorable men players this yere', followed by an entry stating 'paid to the Lord $\langle\ldots>$ players to the Erle of Suffolk players to my Lord Prevay Seall players and to oyer honorable men players ... xxvij s ij d' (434 pence). Since there is no indication of how many 'oyer honorable men players' there were, perhaps we can surmise the share paid to the king's entertainers was around 240 pence. That was the amount paid them in 1527 and 1535, and it makes sense that the king's players would receive the largest payment. York's records show that in 1541 the entertainers of the duke of Suffolk and the earl of Sussex were paid, respectively, 48 and 55 pence. Hence, for a probable total of 1,934 pence from five counties, Kent provided over $19 \%$ of that total. 45

To reinforce the financial advantages of performing in Kent, let us summarize the touring activities of three other acting companies during the reign of Elizabeth, when acting companies, though patronized by peers, had become semiautonomous, commercial enterprises. ${ }^{46} \mathrm{Oft}$ mentioned in Shakespeare studies are Sussex's Men (a continuous patronage by three successive earls of Sussex, Thomas, Henry, and Robert Radcliffe), Lord Strange's Men (patron, Ferdinando Stanley), 
and the Admiral's Men (patron, Charles Howard). Sussex's Men appear nineteen times in Kent's dramatic records, earning a total of 1,656 pence. They appear in Shropshire's records only once earning 120 pence, in Sussex's records twice, earning 200 pence, in York four times, earning 1,280 pence. Sussex's men are not mentioned in Devon's records. Lord Strange's men appear ten times in Kent, earning 1,608 pence, thrice in Devon, earning 304 pence, once in Shropshire, earning 480 pence, and twice in Sussex, earning 280 pence. They do not appear in York's dramatic records. Kent's dramatic records list twenty performances by the Admiral's Men, totaling 3,744 pence in income. They played in Devon twice, earning 360 pence, in Shropshire twice, earning 500 pence, in Sussex five times, for a total of 640 pence, and thrice in York, earning 1,080 pence. ${ }^{47}$ Though these records cover a stretch of thirty-five years (1568-1603), the amounts are still telling. Kent yielded these three companies 7,008 pence. The combined earnings from Devon, Shropshire, Sussex, and York were only 1,400 pence. That means that over those thirty-five years, revenues from Kent produced over $83 \%$ of the earnings that Sussex's, Strange's, and the Admiral's Men derived from these five counties.

As noted in this essay's opening paragraph, Kent's dramatic records list frequent performances by royal and aristocratic entertainers. Yet before outlining that phenomenon, we must remember that the main raison d'être for these entertainers was to entertain their royal and aristocratic patrons. Perhaps one reason they toured was to supplement the stipends they received from their patrons. Yet these performers were the servants of their patrons, and would not be touring unless given leave by their masters. Hence, their mere presence in the localities may have been what Leonard Tennenhouse calls Power on Display (to quote his book title). ${ }^{48}$ Travelling entertainers indirectly served to represent, 'advertise', their patrons' status and power. Also, perhaps, they may have served as intelligencers and messengers, ${ }^{49}$ and though our knowledge of repertories is very slim, the players' offerings may have served to promote policies advocated by their patrons. Such certainly was the case during the religious reforms of Henry VIII and Edward VI, and some evidence suggests increased touring by the entertainers of the great magnates coincided with times when they sought to raise their status and power. ${ }^{50}$

I believe the frequency of performances by the entertainers of English monarchs in Kent suggests such purposes. Between the appearance of Edward I's 'ystrioni' in Canterbury in 1277 and Charles I's players in Lydd in 1635 (a period of 358 years), County Kent saw over 770 performances by the entertainers of every reigning monarch, with the exception of Henry V and Edward V (who was 
deposed within three months of his succession). ${ }^{51}$ How does this phenomenon compare with the other four selected counties?

First, the entertainers of Edward I, Edward II, Edward III, Richard II, Henry IV, Richard III, James I, and Charles I - all present in Kent's dramatic records - did not perform in all of our four comparison counties. Devon's first royal entertainer was Henry IV's piper who performed at Exeter in 1400. Between that date and the appearance of Charles I's players in 1634 at Dartmouth ${ }^{52}$ (234 years) records show a total of 104 performances by royal entertainers. Shropshire's first royal entertainers were those of Henry IV at Shrewsbury in 1413. The last record of royal entertainers concerns the trumpeters of Charles I in $1642.5^{33}$ In those 229 years Shropshire's dramatic records list ninety-one performances by royal entertainers. Sussex matches that number between the years when, in 1346 Edward III's minstrels performed at Battle Abbey and Queen Elizabeth's Men performed at Rye in $1596^{54}$ (a period of 251 years). York's first record of royal entertainers notes a performance by minstrels of Henry VI in 1442. Its last record references the performance of Charles I's trumpeters in $1642^{55}$ (a period of 200 years). The total number of performances in all four counties by entertainers of England monarchs is 363: in other words, just a bit over half of those that occurred in Kent.

The chief royal officer in Kent and neighboring Sussex was the lord warden of the Cinque Ports. Dramatic records from those counties list 300 performances by entertainers of the lords warden. Almost every lord warden of the Cinque Ports - from Henry, duke of Gloucester in 1423 until William, Lord Cobham in 1597 - had entertainers touring in those two counties. ${ }^{56}$ The almost seamless continuity year by year of performances by lords warden's entertainers suggests, perhaps, there existed a local group of performers in Kent attached to the office of lord warden, especially since the performers of the following lords warden never appear in dramatic records other than those of Kent and Sussex: Sirs Thomas Cheyne, Edward Guildford, and Edward Poynings, and Lord Cobham.

That massive display of royal power makes sense for Kent. Kent was a county lacking controls found in most other counties. It lacked major secular lords, and possessed a large number of chartered towns and other semi-independent liberties, which made much of the county almost independent of the royal sheriffs. In fact, the office of lord warden was created after the Cinque Ports sided with Simon de Montfort in the Second Barons' War against Henry III (1264-70), and from Kent came Wat Tyler's rebellion in 1381, Jack Cade's rebellion in 1450, the last gasp of resistance to the restoration of Edward IV in 1471, and the beginnings of Buckingham's rebellion against Richard III in 1483 (and later the threat of revolt 
against Edward VI in 1549-50 and Wyatt's rebellion against Mary in 1554). ${ }^{57}$ No doubt England's monarchs realized they needed more eyes and ears, and their presences well advertised and represented, in such an independent-minded and turbulent county.

Frequent appearances by entertainers of several queens-consort also augmented the royal 'presence' in Kent. In Canterbury, 1356, the entertainers of Queen Philippa, wife of Edward III, were the first to perform there. The last to perform in Kent were the players of James I's wife, Queen Anna of Denmark, at New Romney in 1619.58 Between these two groups of performers were those of the following queens, their husbands in parentheses: Margaret of Anjou (Henry VI), Elizabeth Woodville (Edward IV), Anne Neville (Richard III), Elizabeth of York (Henry VII), and Catherine of Aragon, Anne Boleyn, and Catherine Parr (three of the six wives of Henry VIII). After Henry's death, for fifty-six years England's monarchs were a boy-king (Edward VI) and two queens regnant (Mary and Elizabeth). So the next queen-consort's performers in Kent were those of Anna of Denmark. ${ }^{59}$ Entertainers of Queen Henrietta Maria (wife of Charles I) played only in London at the Inns of Court, with three exceptions: an appearance at Oxford in 1629, at Coventry in 1635, and at Norwich in 1633, where they were paid 240 pence, but ordered from the town. ${ }^{60}$ All told, there were 144 appearances by England's queens-consort in Kent. As an aside, Henry VIII's fourth and fifth wives did not last long enough to have travelling entertainers. Anne of Cleves divorced after six months, and Catherine Howard was executed about eighteen months after her wedding. ${ }^{61}$ Henry's third wife, Jane Seymour, who died eighteen months after her marriage from complications in childbirth, did not have entertainers perform in Kent, but they did appear in Shropshire shortly after her marriage. ${ }^{62}$ Queens Anne Boleyn, Jane Seymour, and Catherine Parr may have been advertising their status as the 'new' queen. And Anne Boleyn and Catherine Parr, both avid supporters of Protestant reform, were probably using their performers to present interludes emphasizing Protestant ideas. ${ }^{63}$

How often did these queen's entertainers perform in Devon, Shropshire, Sussex and York? The dramatic records reveal that four of them - Queens Margaret of Anjou, Anne Neville, Catherine of Aragon, and Catherine Parr — never had entertainers in any of the four counties, though their entertainers did visit a few other counties. ${ }^{64}$ Queen Elizabeth Woodville's are listed in records from Devon, Shropshire, and Sussex, but not from York. Entertainers of her daughter, Elizabeth of York, match those of her mother. Anne Boleyn's entertainers appear in Devon's records, but not in those from Shropshire, Sussex, or York. Jane Seymour's entertainers did perform in Shropshire, but not in the other three counties. Anna of 
Denmark's entertainers appear only in Devon's and Shropshire's dramatic records. ${ }^{65}$ As mentioned above, Queen Henrietta Maria's entertainers did almost no touring. The records from our four comparison counties yield only thirty-seven performances by the entertainers of England's queens-consort as opposed to 144 in Kent. Hence, the various queens' entertainers performed five times more often there than in the combined totals from Devon, Shropshire, Sussex, and York.

Entertainers touring under the name of several princes of Wales also enhanced the royal 'presence' in Kent. For 300 years, from the first to the last notice in Kent's dramatic records - a performance at Canterbury in 1339 by entertainers of Prince Edward of Woodstock (the 'Black Prince'), a performance by entertainers of the future Charles II at Dover - entertainers of many princes of Wales performed in Kent, ${ }^{66}$ save those of the future Edward II, Henry V, Richard II, and two Prince Edwards, the sons of Henry VI and Richard III. Those princes of Wales whose entertainers performed in Kent include: Edward of Woodstock (the 'Black Prince'), the future Edward V, Arthur Tudor (eldest son of Henry VII), the future Henry VIII, the future Edward VI, Henry Frederick (eldest son of James I), and the future Charles I and Charles II. ${ }^{67}$ In total, entertainers of England's princes of Wales performed 158 times in Kent.

How does this statistic compare with counties Devon, Shropshire, Sussex, and York? As was the case with the queens-consort, not every prince of Wales had entertainers who played in all four counties. Devon was visited by entertainers of the 'Black Prince', the future Henry V, the future Edward V, and the future Charles I. ${ }^{68}$ Shropshire's records list performances by the entertainers of the future Henry V, Edward of Westminster (son of Henry VI), the future Edward V, Arthur Tudor, Henry Frederick, the future Charles I, and Charles II. ${ }^{69}$ Sussex's dramatic records list performances by entertainers of the 'Black Prince', the future Edward V, Arthur Tudor, and the future Henry VIII, Edward VI, and Charles I. ${ }^{70}$ York's records, like Devon's, show only four visits by entertainers of the princes of Wales: the future Edward V, Arthur Tudor, and the future Charles I and II. ${ }^{71}$ The total number of performances by entertainers of England's princes of Wales appearing in the dramatic records of Devon, Shropshire, Sussex, and York is seventy-nine, only half the number found in the records for Kent.

Even performers attached to the heirs 'in reserve' toured. Entertainers of four dukes of York - Edmund Langley, Richard of York, Henry (VIII), and Charles (I), second sons respectively of Edward III, Edward IV, Henry VII, and James I - are found in the dramatic records of Kent and other counties, and so too are those of Lady Elizabeth, James I's daughter and third in line. Collectively 
their entertainers played Kent fourteen times. ${ }^{72}$ Collectively in Devon, Shropshire, Sussex, and York, their entertainers appeared eleven times. ${ }^{73}$

Before the reign of Edward IV entertainers of princes of Wales and other potential heirs to the throne are not frequently found in England's dramatic records. Edward IV may have begun a practice followed by his successors of using touring entertainers to advertise the status of his heirs. The first record for the appearance of Prince Edward's entertainers was in 1473, when he was only three years old. Henry VII and Henry VIII moved even more quickly. Entertainers for Prince Arthur appear in dramatic records in 1487, when he was one, and the entertainers of Henry VIII's heir, Edward, began touring within months of his birth. ${ }^{74}$

Along with those already mentioned above — the earls of Leicester, Essex, Sussex, the Lord Admiral, and Lord Strange - the entertainers of many of England's great and prominent magnates performed in Kent. Since tracing them all would be tedious, running into the thousands, a sampling should suffice. Entertainers of three generations of the Stafford dukes of Buckingham appear in Kent's dramatic records twenty-six times from 1451 to 1520 . Entertainers of five successive dukes of Norfolk appear in those records twenty times from 1385 to 1543. Those of seven earls of Arundel appear 103 times from 1339 to 1561, and those of five earls of Oxford appear fifty-four times between 1353 and 1594, for a total of 360 appearances by entertainers of these four groups of magnates. ${ }^{75}$ To be sure, the numbers may be somewhat skewed a bit by the fact that both Humphrey Stafford (d. 1460), duke of Buckingham, and William FitzAlan (d. 1487), earl of Arundel, were lords warden of the Cinque Ports.

How do these numbers compare with the records from Devon, Shropshire, Sussex, and York? Performers of the dukes of Buckingham appear six times in Devon's dramatic records, those of the dukes of Norfolk seven times, those of earls of Arundel six times, and those of the earls of Oxford fourteen times. Shropshire's records reveal eight appearances there by entertainers of the dukes of Buckingham, twenty-one by those of the earls of Arundel, seven by those of the earls of Oxford, and none by those sponsored by the dukes of Norfolk. Sussex's accounts record seven appearances by the performers of the dukes of Buckingham, four by those of the dukes of Norfolk, thirty-nine for those of the earls of Arundel, and twenty-seven by those of the earls of Oxford. Finally, York's records list two appearances for the entertainers of the dukes of Buckingham, four for the dukes of Norfolk, two for the earls of Oxford, and none for the earls of Arundel, ${ }^{76}$ for a grand total from all four counties of 154 , less than half the number of appearances in Kent. 
Forthcoming REED volumes will not likely reveal an English county with more troupes of touring entertainers than those who performed in County Kent, especially since the numbers from Kent present in Kent: Diocese of Canterbury will expand when Kent: Diocese of Rochester is published. Data from the current REED volumes, and augmented by other sources such as the Malone Society's publications for Norfolk and Suffolk, reveals performances by touring entertainers at locations in thirty-five English counties. So far the data for such activity in Kent far surpasses that in other counties. For instance, of about 2,300 appearances by entertainers travelling under the patronage of England's reigning monarchs between 1277 and 1642, about one third of those appearances were in Kent. Kent's history of rebellion up into the reign of Elizabeth probably has something to do with the consistent 'advertisement' of royal power through visiting performer-servants, but Kent also offered them, and the performer-servants of other magnates, opportunities not found in other counties. With its traditions of local drama, relatively prosperous citizenry, and numerous municipalities, Kent offered touring performers the chance to perform, and earn money, at several localities within a short space of time. 


\section{Notes}

1 Entertainers and performers denote patronized persons whose primary function was to provide entertainment. Records in Latin mention histriones, mimis, luditores, and lusitores. Histriones and mimi probably designate some sort of actors, and luditores and lusitores are generic terms for players. See William Smith, A Smaller Latin-English Dictionary, rev. ed., J.F. Lockwood (New York, 1962), 311, 410-11, 435. Those identified as minstrels may be actors, musicians, dancers, all of these. Bearwards and other animal keepers, jesters, jugglers, and acrobats (tumblers) usually are specified, as are musicians (trumpeters, pipers, harpists, drummers, and waits).

2 Alan B. Somerset, ed., REED: Shropshire (Toronto, 1994), 129; for Skipton Castle, John T. Murray, English Dramatic Companies 1558-1642 (New York, 1963), 2.255; John M. Wasson, 'Elizabethan and Jacobean Touring Companies', Theatre Notebook 42 (1988), 51-7.

3 James M. Gibson, ed., REED: Kent, Diocese of Canterbury (Toronto, 2002), 28, 530, and passim. The volume for the diocese of Rochester is not yet published. For now some Kentish records outside the Canterbury diocese can be found in Giles E. Dawson, ed., Records of Plays and Players in Kent, 1450-1642 (Oxford, 1965), 10, 12, 16, 20, 24, 26-33, 38-45, 51, 57, 59, 60-9, 73, 75-7, 80, 83-7, 94, 95, 98-117, 120, $122,125-7,129,131-8,144,146,148-54$. Other records exist in John H. Astington, English Court Theatre 1558-1642 (Cambridge, 2008), 226, 234, 240; Scott McMillin and Sally-Beth MacLean, The Queen's Men and Their Plays (Cambridge, 1998), 176, 178-9, 185, 188; E.K. Chambers, The Elizabethan Stage (Oxford, 1965), 2.118 and 4.147, 151, 160-3, 165; Ian Lancashire, Dramatic Texts and Records of Britain: A Chronological Topography to 1558 (Toronto, 1984), 140, 145, 352, 362, 389-93.

4 R.W. Ingram, ed., REED: Coventry (Toronto, 1981), 'Introduction', lii. A few citations concerning touring troupes appear in other locales: Caludon and Clinton Castles, Maxstoke Priory, Stratford-upon-Avon, and the town of Warwick. See Elza Tiner, 'Patron and Travelling Companies in Warwickshire', Early Theatre 4.1 (2001), 36-8, https://doi.org/10.12745/et.4.1.610; Murray, Dramatic Companies, 2.402; Chambers, Stage, 2.101, 103, 118, 127, 164, 221; Lancashire, Dramatic Texts, 278, 364, 381; McMillan and MacLean, Queen's Men, 182-3, 188.

5 Sally-Beth MacLean, 'At the End of the Road: An Overview of Southwestern Touring Circuits', Early Theatre 6 (2003), 7-21, https://doi.org/10.12745/et.6.2.654.

6 John M. Wasson, ed., REED: Devon (Toronto, 1986), 241, 320. See ibid., 23, 30-6, 40-53, 62-72, 75-99, 101, 109-18, 210-35, 138-9, 147-8, 150, 154-66, 173-6, 
189, 186-90, 192, 207, 213-48, 250-7, 261, 265-71, 279-82, 306, 308, 327; Murray, Dramatic Companies 2.6, 57, 197-8, 380-2.

7 Cameron Louis, ed., REED: Sussex (Toronto, 2000), 27, 162. See ibid., 14-18, 33, 34, 38, 39, 44-140, 149, 182-7.

8 Somerset, ed., REED: Shropshire, 50, 52, 74-93, 104-5, 109-13, 127-82, 185-203, 205-10, 220-1, 232, 235, 238, 242, 245, 247-8, 276-7, 284-8, 290, 293, 300-3, 306, 308, 320, 325, 335, 352-4; Murray, Dramatic Companies, 2.324; Lancashire, Dramatic Texts, 372.

9 Alexandra F. Johnston and Margaret Rogerson, eds, REED: York (Toronto, 1979), 9, 65-77, 80-1, 85-7, 94, 181, 203, 206, 214, 217, 220-1, 225, 229, 323, 234, 248, 259, 269, 273, 281, 330, 376, 382, 396-7, 403, 409, 413, 418-19, 430, 435-6, 441-2, 449, 455, 460, 463-4, 471, 476, 479, 481-2, 486-8, 491, 494, 496, 501, 507, 509, 517, 521-2, 524, 528, 536, 638-9, 664, 580-1, 593-4, 608, 615; McMillin and MacLean, Queen's Men, 175, 177, 185; Murray, Dramatic Companies, 2.205, 255-7, 286, 411; J.T. Fowler, Memorials of the Abbey of St. Mary's Fountains (Durham, 1898), 59-61; Glynne Wickham, Early English Stages, 4 vols (London, 1980), 1.332, 334, 336, 338; Lancashire, Dramatic Texts, 123, 156, 226, 350, 359, 366, 368, 401-2.

10 Patricia Hyde and Michael Zell, 'Governing the County', in Early Modern Kent 1540-1640, ed. Michael Zell (Woodbridge, UK, 2000), 10; Jacqueline Bower, 'Kent Towns', Early Modern Kent, ed. Zell, 146-7, 151, 160-3.

11 Gibson, ed., REED: Kent, 24, 26-33, 38-42, 44-5, 51, 310-16, 331-8, 348, 350-3, 356, 359, 362, 367, 371, 374, 376-9, 381, 384, 387, 400, 406, 410-18, 421-85, 493-518, 590.

12 Wasson, ed., REED: Devon, xv-xvii.

13 Sally-Beth MacLean, 'At the End of the Road', 18, 19.

14 Wasson, ed., REED: Devon, 70-99, 101, 109-92.

15 Somerset, ed., REED: Shropshire, 2.359-66, 369-72.

16 Ibid., 79, 127-41, 144-5, 148-57, 159-82, 185-210, 221, 232-3, 235, 238, 242, $245-8,276-7,284-8,290,293,300-3,306-8$.

17 Louis, ed., REED: Sussex, xiv-xviii, xxvii-xxix; Encyclopaedia Britannica, $11^{\text {th }}$ edition (Cambridge, 1911), XXIII.949-50.

18 Louis, ed., REED: Sussex, 38-9, 44-151.

19 Johnston and Rogerson, eds, REED: York, x-xiii; R.W. Griffiths, 'Local Rivalries and National Politics: The Percies, the Nevilles, and the Duke of Exeter, 1452-55', Speculum 43 (1968), 590-610; 'York (City)', Encyclopaedia Britannica, XXVII.928-9.

20 Johnston and Rogerson, eds, REED: York, 65-77, 80-6, 94, 144, 181, 203, 206, 214, 220-5, 229, 232-4, 237, 241, 243, 248, 259, 269, 273, 281, 330, 376, 382, 396-7, 403, 409, 413, 418-19, 430, 435-6, 441-2, 449, 455, 460, 462-4, 471, 473, 476, 
479, 481-2, 486-8, 501, 507-9, 517, 521-4, 528, 533, 536, 538-9, 558, 564, 568, 580-1, 593-4, 608, 615.

21 Gibson, ed., REED: Kent, 114, 417, 475, 733-79, 782, 790, 794-812, 846.

22 See the following articles in Early Modern Kent, ed. Zell: 'Introduction', 3 (for Kent's population in 1550); Hyde and Zell, 'Governing the County', 7-21, 24-5; Bower, 'Kent Towns', 142-52, 163; Zell, 'Landholding and the Land Market', 47, 63; Thirsk, 'Agriculture in Kent, 1540-1640', 77, 83-4, 87; Andrewes, 'Industries in Kent, c. 1500-1640', 128-35.

23 The towns: Appledore, Ash, Beneden, Bethersden, Boughten, Brookland, Canterbury, Dover, Elham, Faversham, Folkestone, Great Chart, Hamstreet, Harrietsham, Herne, Hythe, Lydd, Maidstone, New Romney, Reading Street, Rochester, Sandwich, Sittingbourne, and Tenterden. See Gibson, ed., REED: Kent, 67, 69-71, 149, 322, 331, 336, 338, 342, 354, 366, 368, 370-1, 375, 386, 401, 411, 413, 575, 616-17, 621, 623, 646-59, 663-5, 668-83, 686-7, 692, 733-5, 751-2, 760, 762, 765-6, 769, 773-4, 825, 828-30, 908-9; Dawson, ed., Kent, 24, 26, 28-33, 38, 40, $42,83-6,94-5,98-104,120,122,125-34,148-9$.

24 Ibid., 665, 674, 751, 765. For Appledore's population see Bower, 'Kent Towns', in Early Modern Kent, ed. Zell, 143.

25 Counties Berkshire: Lancashire, Dramatic Texts, 356, 368; Cambridge: Alan H. Nelson, ed., REED: Cambridge (Toronto, 1989), 49, 68; Cornwall: Rosalind Conklin Hays, c.e. McGee, Sally Joyce, and Evelyn S. Newlyn, eds., REED: Dorset, Cornwall (Toronto, 1999), 495, 507; Devon: Wasson, ed., REED: Devon, 23, 39, 239; Essex: Lancashire, Dramatic Texts, 157-68; Gloucester: Audrey Douglas and Peter Greenfield, eds, REED: Cumberland, Westmorland, Gloucestershire (Toronto, 1986), 347; Lancashire: David George, ed., REED: Lancashire (Toronto, 1991), 167-8; Leicester: Murray, Dramatic Companies, 2.300; David Galloway and John Wasson, eds, Records of Plays and Players in Norfolk and Suffolk (Oxford, 1980), 88, 93. Shropshire: Somerset, ed., REED: Shropshire, 193; Suffolk: Galloway and Wasson, eds, Norfolk/ Suffolk, 232; Sussex: Louis, ed., REED: Sussex, 46, 49, 50, 52, 54, 57, 59-61, 63, 66-9, 71-3, 75-7, 79, 80, 89-90, 92-7, 185-6; Warwick: Lancashire, Dramatic Texts, 354; Worcester: David N. Klausner, ed., REED: Herefordshire, Worcestershire (Toronto, 1990), 501; York: Lancashire, Dramatic Texts, 359, 366.

26 Counties Cambridge, Durham, Essex, Lincoln, London, Norfolk, Northumberland, Somerset, Sussex, Warwick, and York. See Gibson, ed., REED: Kent, 71, 354, 368, 651, 623, 651, 669, 674, 676, 735.

27 Devonshire towns: Colyton, Exeter, Modbury, St Budeaux, Plymouth, Stonehouse, Tavistock, Tawton, and Totnes. Other counties: Bristol, Cornwall, Dorset, Gloucester, Hampshire, Huntingdon, Kent, London, Somerset, Wiltshire, and York. See 
Wasson, ed., REED: Devon, 23, 30-3, 35-9, 43-5, 52-3, 62-7, 84-6, 93, 134, 174 , 207, 234-42, 280-1, 306, 327.

28 Shropshire towns: Claverley, Shrewsbury, Whitechurch, Wrexham. See Somerset, ed., REED: Shropshire, 82, 168, 170, 173, 175, 177, 193, 203, 335, 352-5.

29 Sussex towns: Chichester, Ipswich, Hastings, Peasmarsh, West Malling, West Tarring, and Winchelsea. Counties represented: Berkshire, Buckingham, Cambridge, Cumberland, Esssex, Lincoln, Norfolk, Stafford, Warwick, Worcester, and York. See Louis, ed., REED: Sussex, 46, 49-50, 52-4, 57, 59-61, 63, 65-73, 75-81, 85, 89-98; Gibson, ed., REED: Kent, 771.

30 Yorkshire towns: Beverley, Hull, Riccal, and York. Counties represented: Bedford, Devon, Essex, Kent, Lincoln, Suffolk, Sussex, Warwick, and Wales. See Johnston and Rogerson, eds, REED: York, 382; Wickham, Stage, 332, 336, 338; Murray, Dramatic Companies, 2.286; Fowler, Memorials, 59-61, 67, 77.

31 Dawson, ed., Kent, 189-202; Bower, 'Kent Towns', Early Modern Kent, ed. Zell, 146.

32 Dawson, ed., Kent, 207-11.

33 See Lawrence M. Clopper, ed., REED: Chester (Toronto, 1979), 66; M. St. Clare Byrne, Elizabethan Life in Town and Country (London, 1961), 309; W. Holland and John James Raven, eds, 'Notes from the Records of Smarden Church', Archaeologia Cantiana ix (1874), 92; G.D. Ramsay, ed., John Isham Mercer and Merchant Adventurer. Two Account Books of a London Merchant in the Reign of Elizabeth I Gateshead, Durham, 1962), 135.

34 Gibson, ed., REED: Kent, 42; Dawson, ed., Kent, 207, 217.

35 For brevity I give only the first listing for each town from Gibson, ed., REED: Kent. Boxley, 905; Canterbury, 31; Chartham, 51; Dover, 309; Eastry, 65; Faversham, 540; Folkstone, 575; Fordwich, 596; Hecington, 150; Hythe, 612; Ickham, 70; Isle of Sheppy, 926; Lydd, 647; Maidstone, 715; New Romney, 733; Rochester, Sandwich, 828; Ipswich: McMillan and MacLean, Queen's Men, 188; Gravesend and Rochester: Dawson, ed., Kent, 80, 144; Eltham: Lancashire, Dramatic Texts, 389.

36 Wasson, ed., REED: Devon, passim.

37 Somerset, ed., REED: Shropshire, 80, 162, 335, 352-3.

38 Louis, ed., REED: Sussex, passim.

39 Johnston and Rogerson, eds., REED: York, passim. McMillan and MacLean, Queen's Men, 185; Murray, Dramatic Companies, 2.205, 255, 286; Wickham, Stage, 332-8; Lancashire, Dramatic Texts, 156, 350, 359, 368. Important essays on many aspects of drama in York and Yorkshire can be found in David Klausner and Karen Sawyer Marsalek, eds, 'bring Furth the Pagants': Essays in Early English Drama Presented to Alexandra F. Johnston (Toronto, 2006) and David Klausner, ed., The City and the 
Parish: Drama in York and Beyond: Shifting Paradigms in Early English Drama Studies by Alexandra F. Johnston (New York, 2017).

40 James H. Forse, 'Getting Your Name Out There: Traveling Acting Companies and Aristocratic Prestige in Tudor England', Quidditas 26-7 (2006), 91-140, http:// humanities.byu.edu/rmmra.

41 Gibson, ed., REED: Kent, 144, 179, 225-6, 650, 582, 632-3, 704, 719, 802-3; McMillin and MacLean, Queen's Men, 179; Wasson, ed., REED: Devon, 166; Louis, ed., REED: Sussex, 133-4; Ingram, ed., REED: Coventry, 324.

42 Gibson, ed., REED: Kent, 197, 467, 548, 699, 799; Wasson, ed., REED: Devon, 156, 239-40, 280; Louis, ed., REED: Sussex, 120.

43 Gibson, ed., REED: Kent, 480, 559, 633, 703, 802; Louis, ed., REED: Sussex, 133; Johnston and Rogerson, eds, REED: York, 435.

44 Gibson, ed., REED: Kent, 154, 440, 543, 692, 774; Wasson, ed., REED: Devon, 138; Somerset, ed., REED: Shropshire, 197-8; Louis, ed., REED: Sussex, 308; Johnston and Rogerson, eds, REED: York, 269.

45 Elizabeth: Wasson, ed., REED: Devon, 166; Gibson, ed., REED: Kent, 225-6, 560, 562, 632-3, 704, 719, 803; Somerset, ed., REED: Shropshire, 88; Louis, ed., REED: Sussex, 133-4; Dawson, ed., Kent, 144; McMillin and Maclean, Queen's Men, 174. Leicester: Wasson, ed., REED: Devon, 156, 240, 280; Gibson, ed., REED: Kent, 197, 467, 548, 699, 700; Louis, ed., REED: Sussex, 120. Essex: Gibson, ed., REED: Kent, 560, 633, 704, 720; Louis, ed., REED: Sussex, 133; Johnston and Rogerson, eds, REED: York, 430. Henry VIII: Wasson, ed., REED: Devon, 138; Gibson, ed., REED: Kent, 154, 440, 543, 774; Somerset, ed., REED: Shropshire, 198; Louis, ed., REED: Sussex, 107; Johnston and Rogerson, eds, REED: York, 243, 259, 269, 273.

46 See Gerald Eades Bentley, The Profession of Player in Shakespeare's Time, 1590-1642 (Princeton, 1984).

47 Gibson, ed., REED: Kent, 196-8, 205, 213, 219, 221, 227, 449, 467-9, 477-8, 544, 549, 554, 558, 560-1, 581, 583, 594, 633, 638, 704, 721, 803; Wasson, ed., REED: Devon, 45, 156, 163-5, 251, 156, 248; Somerset, ed., REED: Shropshire, 276-7; Louis, ed., REED: Sussex, 123, 126, 128, 134-6; Johnston and Rogerson, eds, REED: York, 396, 430, 435, 455, 509.

48 Leonard Tennenhouse, Power on Display (New York, 1986).

49 Records from Exeter (1533) note 6s. 8d paid to King Henry VIII's minstrels 'that brought the letters to Master Mayor' (Wasson, ed., REED: Devon, 132). Records from Canterbury (1340) and Battle Abbey (1346) list payments to messengers and entertainers of Prince Edward of Woodstock (the 'Black Prince'), his father Edward III, his mother Philippa of Hainault, and other nobles (Gibson, ed., REED: Kent, 41 and Louis, ed., REED: Sussex, 182). Probably the messengers also were their 
entertainers. Also see McMillin and MacLean, Queen's Men, 22-32, Sally-Beth McLean, 'The Politics of Patronage: Dramatic Records in Robert Dudley's Household Books', Shakespeare Quarterly 44 (1993), 175-82, and Forse, 'Getting Your Name', 118-19.

50 See Greg Walker, Plays of Persuasion: Drama and Politics at the Court of Henry VIII (Cambridge, 1991); Paul Whitfield White, Theatre and Reformation (Cambridge, 1993); Suzanne R. Westfall, Patrons and Performance: Early Tudor Household Revels (Oxford, 1998), 121-2, 134-5, 233; McMillin and MacLean, Queen's Men, 39, 44, 48-9; Forse, 'Getting Your Name', 91-108, 117.

51 For the sake of brevity I cite only the first and last appearance for each monarch with the total number of performances and first and last date in parentheses. Edward I (1: 1277, 1302) Gibson, ed., REED: Kent, 28, 59. Edward II (1: 1309) ibid., 34. Edward III, Kent (28: 1332, 1367) ibid., 39, 310; Sussex (2: 1346, 1358) Louis, ed., REED: Sussex, 162-3. Richard II, Kent (1: 1377) Gibson, ed., REED: Kent, 59; Sussex (2: 1381, 1394) Louis, ed., REED: Sussex, 183. Henry IV, Kent (1: 1403) Gibson, ed., REED: Kent, 60; Devon (6: 1400, 1413) Wasson, ed., REED: Devon, 86. Henry V, Devon (2: 1417, 1418) ibid., 77, 82. Henry VI, Kent (52: 1432, 1456) Gibson, ed., REED: Kent, 73, 653; Devon (6: 1426, 1458) Wasson, ed., REED: Devon, 30, 88; Shropshire (7: 1441, 1457) Somerset, ed., REED: Shropshire, 132, 140; Sussex (5: 1425, 1457) Louis, ed., REED: Sussex, 47, 135; York (12: 1442, 1453) Johnston and Rogerson eds, REED: York, 65, 83. Edward IV, Kent (28: 1465, 1480) Gibson, ed., REED: Kent 167, 545; Devon (1: 1481) Wasson, ed., REED: Devon, 36; Shropshire (1: ca 1466) Somerset, ed., REED: Shropshire, 24; Sussex (2: ca 1480) Louis, ed., REED: Sussex, 51, 184; York (3: 1462, 1479) Wickham, Stage, 332-4. Richard III, Kent (4: 1483, 1484) Gibson, ed., REED: Kent, 83, 621. Henry VII, Kent (52: 1487, 1509) ibid., 85, 106; Devon (28: 1490, 1509) Wasson, ed., REED: Devon, 109, 118; Shropshire (7: 1486, 1506) Somerset, ed., REED: Shropshire, 156, 166; Sussex (17: 1486, 1506) Louis, ed., REED: Sussex, 59, 77; York (5: 1486, 1508) Johnston and Rogerson, eds, REED: York, 144, 206. Henry VIII, Kent (202: 1516, 1546) Gibson, ed., REED: Kent, 83, 620; Devon (73: 1509, 1537) Wasson, ed., REED: Devon, 39, 110: Shropshire (45: 1509, 1547) Somerset, ed., REED: Shropshire, 70, 168; Sussex (41: 1509, 1546) Louis, ed., REED: Sussex, 78, 119; York (19: 1516, 1543) Johnston and Rogerson, eds, REED: York, 214, 281. Edward VI, Kent (25: 1547, 1552) Gibson, ed., REED: Kent, 167, 545; Sussex (4: 1550, 1553) Louis, ed., REED: Sussex, 112, 114. Mary I, Kent (13: 1556, 1557) Gibson, ed., REED: Kent, 457, 555; Devon (5: 1555, 1557) Wasson, ed., REED: Devon, 147-8; Shropshire (2: 1554, 1555) Somerset, ed., REED: Shropshire, 81, 90; Sussex (1: 1557) Louis, ed., REED: Sussex, 116; York (2: 1556, 1557) Murray, Dramatic Companies, 2.205. Elizabeth I, Kent (214: 1558, 1601) Gibson, ed., REED: Kent, 182, 805; Devon 
(28: 1560, 1601) Wasson, ed., REED: Devon, 43, 47; Shropshire (25: 1559, 1601) Somerset, ed., REED: Shropshire, 206, 286; Sussex (20: 1558, 1596) Louis, ed., REED: Sussex, 117, 139; York (20: 1562, 1602) Johnston and Rogerson, eds, REED: York, 501 and Murray, Dramatic Companies, 2.205. James I, Kent (34: 1605, 1625) Gibson, ed., REED: Kent, 495, 712; Devon (3: 1603-1605) Wasson, ed., REED: Devon, 48, 188; Shropshire (4: 1611, 1624) Somerset, ed., REED: Shropshire, 104, 210, 288; York (2: 1609, 1624) Murray, Dramatic Companies, 2.255. Charles I, Kent (15: 1626, 1634) Gibson, ed., REED: Kent, 526, 868; Devon (6: 1625, 1643) Wasson, ed., REED: Devon, 69, 271; Shropshire (1: 1642) Somerset, ed., REED: Shropshire, 320; York (14: 1628, 1642) Johnston and Rogerson, eds, REED: York, 1, 615.

52 Wasson, ed., REED: Devon, 69, 80.

53 Somerset, ed., REED: Shropshire, 128, 320.

54 Louis, ed., REED: Sussex, 139, 162.

55 Johnston and Rogerson, eds, REED: York, 65, 615.

56 Records (to date) show extensive touring by performers attached to the lord warden Humphrey duke of Gloucester, lord protector, James Fiennes Baron Saye, Humphrey Stafford duke of Buckingham, Richard Woodville earl of Rivers, Richard Neville earl of Warwick, William Fitz Alan earl of Arundel, Henry prince of Wales (future Henry VIII), Sir Edward Poynings, Sir Edward Guildford, George Boleyn Viscount Rocheford, Henry Fitzroy duke of Richmond, Arthur Plantagenet viscount Lisle, Sir Thomas Cheyne, and William Brooke Baron Cobham. See Gibson, ed., REED: Kent, 64, 72, 99-103, 156, 158, 170-3, 181, 197-8, 320-5, 328-30, 334-46, 348, 350-2, 354-7, 359-71, 387, 389-95, 398-401, 405-6, 408, 410-1, 413, 416-17, 422 , 424-6, 436-8, 440-58, 467-9, 484, 486, 526, 540, 543-6, 551, 557, 575-81, 590, 612-21, 624-9, 673-6, 681-95, 699, 736, 757-9, 782, 799, 832-5, 837-8, 846, 849-51; and Lewis, ed., REED: Sussex, 44-57, 68-77, 79-83, 86-7, 90-2, 95-9, 136, 184-6.

57 Maurice Powicke, The Thirteenth Century, 1216-1307 (New York, 1962), 187-207; Hyde and Zell, 'Governing the County', Early Modern Kent, ed. Zell, 7-21, 24-5; P.J.P. Goldberg, Medieval England 1250-1550: A Social History (New York, 2004), see chapter 13 for the Peasants' Revolt. Also see: M. Bohna, 'Armed force and civic legitimacy in Jack Cade's revolt, 1450', English Historical Review 118 (2003), 563-82, and Charles Ross, Richard III (Berkeley, 1981), 105-19.

58 Gibson, ed., REED: Kent, 47, 810.

59 Using the same format as for the monarchs, I include only the number of performances and first and last date in parentheses. Philippa (12: 1356, 1365) Gibson, ed., REED: Kent, 47, 53; Margaret of Anjou (4: 1452, 1456) ibid., 30, 73; Elizabeth Woodville (24: 1470, 1481) ibid., 357, 744; Anne Neville (7: 1483, 1484) ibid., 84, 671; 
Elizabeth of York (34: 1486, 1498) ibid., 84, 831; Catherine of Aragon (1: 1520) ibid., 838; Anne Boleyn (1: 1535) ibid., 147; Catherine Parr (3: 1543, 1547) ibid., 158, 447; Anna of Denmark (42: 1604, 1619) ibid., 505, 708.

60 Alan H. Nelson and John R. Elliot Jr., eds, REED: Inns of Court (Woodbridge UK, 2010), 217, 234, 346-7, 354; James Stokes, ed., REED: Lincolnshire (Toronto, 2009), 355; John R. Elliot Jr., REED: Oxford (Toronto, 2004), 479; Ingram, ed., REED: Coventry, 439; David Galloway, ed., REED: Norwich (Toronto, 1984), 210.

61 David Starkey, Six Wives. The Queens of Henry VIII (New York, 2003), 627-9, 6478, 668-70.

62 Somerset, ed., REED: Shropshire, 194-5; Starkey, Six Wives, 591, 608.

63 James H. Forse, 'Advertising Status and Legitimacy: or, Why Did Henry VIII's Queens and Children Patronize Travelling Performers?', Early Theatre 16.2 (2013), 61, https://doi.org/10.12745/et.16.2.4. For Anne's and Catherine's possible use of entertainers for Protestant propaganda see White, Theatre and Reformation, 43-50, 129 and Jeffrey Leininger, 'Evangelical "Enterluders": Patronage and Playing in Reformation England', Reformation and Renaissance Review 4 (2002), 48-93, https:// doi.org/10.1558/rrr.v4i1.48.

64 For Margaret of Anjou: Nelson, ed., REED: Cambridge, 30; Gibson, ed., REED: Kent, 43. For Anne Neville: Nelson, ed., REED: Cambridge, 63; Gibson, ed., REED: Kent, 84, 367, 435, 619-20. For Catherine Parr: Nelson, ed., REED: Cambridge, 131; Gibson, ed., REED: Kent, 158, 445, 447; David Galloway, ed., REED: Norwich 1540-1642 (Toronto, 1984), 14; Lancashire, Dramatic Texts, 379.

65 Queen Philippa: Louis, ed., REED: Sussex, 182; Klausner, ed., REED: Hereford/Worcs, 397. Queen Margaret: Nelson, ed., REED: Cambridge, 30. Queen Elizabeth Woodville: Wasson, ed., REED: Devon, 32, 35; Somerset, ed., REED: Shropshire, 149-52; Louis, ed., REED: Sussex, 50-2, 54, 152. Queen Anne Neville: Nelson, ed., REED: Cambridge, 63. Queen Elizabeth of York: Somerset, ed., REED: Shropshire, 162; Louis, ed., REED: Sussex, 59, 62, 69. Catherine of Aragon: Mark C. Pilkinton, ed., REED: Bristol (Toronto, 1997), 30; Klausner, ed., REED: Hereford/Worcs, 417; Elliot, ed., REED: Oxford, 73; Murray, Dramatic Companies, 2.305; David Dymond, ed., The Register of Thetford Priory (Oxford, 1995), 572. Anne Boleyn: Wasson, ed., REED: Devon, 132; Nelson, ed., REED: Cambridge, 106; Klausner, ed., REED: Hereford/Worcs, 523, 526, 530. Jane Seymour: Somerset, ed., REED: Shropshire, 194-5. Catherine Parr: Pilkinton, ed., REED: Bristol, 57; Nelson, ed., REED: Cambridge, 131; Galloway, ed., REED: Norwich, 24; Lancashire, Dramatic Texts, 379. Anna of Denmark: Wasson, ed., REED: Devon, 48, 49, 69, 180, 190; Somerset, ed., REED: Shropshire, 91, 93, 104, 290, 293, 301, 303, 306; Johnston and Rogerson, eds, REED: York, 521. Her players toured extensively elsewhere: counties Berkshire, Cambridge, Cheshire, Dorset, 
Essex, Hampshire, Hereford, Lancashire, Leicester, Lincoln, Norfolk, Nottingham, Oxford, Somerset, Stafford, Suffolk, Warwick, Westmorland, and Wiltshire. See Nelson, ed., REED: Cambridge and Ingram, ed., REED: Coventry; Elizabeth Baldwin, Lawrence M. Clopper, and David Mills. eds, REED: Cheshire Including Chester (Toronto, 2007); Hays, Joyce, and Newlyn, eds, REED: Dorset/Cornwall; Klausner, ed., REED: Hereford/Worcs; George, ed., REED: Lancashire; Stokes, ed., REED: Lincolnshire; Elliot, ed., REED: Oxford; James Stokes and Robert J. Alexander, eds, REED: Somerset including Bath (Toronto, 1996); Douglas and Greenfield, eds, REED: Cumberland/ Westmo/Glouc; Galloway and Wasson, eds, Norfolk/Suffolk, 157-8, 199, 211; Chambers, Stage, 2.233; Murray, Dramatic Companies, 1.202, 2.255-7, 309-13, 333, 376, 399, 466.

66 'Black Prince' (1: 1370); Wasson, REED Devon, 70; Edward V (3: 1474, 1478) Wasson, REED Devon, 358, 360; Charles I (9: 1613, 1623) Wasson, REED Devon, 49-50, 187, 266, 282.

67 Number of performances and first and last dates are in parentheses. Edward of Woodstock (12: 1339, 1374) Gibson, ed., REED: Kent, 41, 58; Edward V (11: 1476, 1481) ibid., 360, 740; Arthur Tudor (19: 1490, 1501) ibid., 75, 97; Henry VIII (34: 1504, 1508) ibid., 107, 390; Edward VI (30: 1538, 1545) ibid., 149, 579); Henry Frederick (6: 1604, 1606) ibid., 565, 723; Charles I (42: 1613, 1625) ibid., 505, 520: Charles II (4: 1633, 1641) ibid., 526, 530.

68 'Black Prince' (1: 1370) Wasson, ed., REED: Devon, 70; Edward V (3: 1474, 1478) ibid., 358, 360; Charles I (9: 1613, 1623) ibid., 49-50, 187, 266, 282.

69 Henry V (2: 1400, 1409) Somerset, ed., REED: Shropshire, 128; Edward of Westminster (2: 1457, 1458) ibid., 140-1; Edward V (3: 1473, 1479) ibid., 148, 153; Arthur Tudor (1: 1492) ibid., 162; Henry Frederick (2: 1608, 1609) ibid., 220, 293; Charles I (2: 1614, 1616) ibid., 306, 308; Charles II (1: 1642) ibid., 320.

70 'Black Prince' (1: 1346) Louis, ed., REED: Sussex, 182; Edward V (1: 1482) ibid., 184; Arthur (7: 1494, 1498) ibid., 61-4, 68, 86; Henry VIII (5: 1503, 1508) ibid., 71-2, 74, 77, 185; Edward VI (13: 1538, 1546) ibid., 17-18, 106-7, 109-10; Charles I (1: 1615) ibid., 150.

71 Edward V (1: c. 1480) Wickham, Stage, 334; Arthur [Tudor] (1: 1499), Johnston and Rogerson, eds, REED: York, 181; Edward VI (1: 1541) Murray, Dramatic Companies, 2.396; Charles I (2: 1619, 1623) Johnston and Rogerson, eds, REED: York, 568; Murray, Dramatic Companies, 2. 255; Charles II (2: 1639, 1642) Johnston and Rogerson, eds, REED: York, 608, 615.

72 Edmund Langley (2: 1375, 1376); Richard of York (2: 1481, 1482); Henry (3: 1496, 1499); Charles (1: 1614); Elizabeth (6: 1611, 1613). Gibson, ed., REED: Kent, 260, 363, 502, 504-5, 624-5, 724, 754. I only include tours by Lady Elizabeth's entertainers 
into 1613, the year she married the Elector Palatine Frederick and moved to the continent with her husband.

73 Wasson, ed., REED: Devon, 36; Somerset, ed., REED: Shropshire, 152, 303; Louis, ed., REED: Sussex, 53, 68, 152, 185; Johnston and Rogerson, eds, REED: York, 59, 636, 538.

74 Edward IV's Prince Edward: Somerset, ed., REED: Shropshire, 148; Henry VII's Prince Arthur: Elliot, ed., REED: Oxford, 30; Henry VIII's Prince Edward: Wasson, ed., REED: Devon, 1537. Before Edward was born, Henry's potential heirs, Princess Mary and his illegitimate son, Henry Fitzroy, had touring entertainers. Forse, 'Advertising Status', 69-76.

75 Buckingham: Gibson, ed., REED: Kent, 63, 70-3, 112, 320, 325, 337-9, 405, 61314, 657, 659-62, 678, 736, 762, 824-5; Norfolk: ibid., 331, 334, 649, 824, 828, 908; Arundel: ibid., 41, 72, 187, 190, 342-5, 348, 350-7, 359-71, 403, 405, 408, 411, 421-3, 461, 547, 615-21, 657, 659, 665-74, 677, 680, 738-46, 750, 756, 802, 824, 830-35, 838; Oxford: ibid., 45, 94, 187, 190, 340, 376-9, 381, 384, 387, 400, 406, 410-11, 418, 455-6, 460, 473, 476-7, 547, 559, 562, 575, 600, 625, 630, 672, 674-7, 679, 696, 716, 756, 759, 761, 765, 827, 830-1, 836-7.

76 Buckingham: Wasson, ed., REED: Devon, 33-5, 89, 98, 217; Somerset, ed., REED: Shropshire, 131-2, 135-6, 138; Louis, ed., REED: Sussex, 45-7, 81; Johnston and Rogerson, eds, REED: York, 67, 70. Norfolk: Wasson, ed., REED: Devon, 31, 34, 38, 147, 220; Somerset, ed., REED: Shropshire, 131-2, 135-6, 138; Louis, ed., REED: Sussex, 45-7, 81. Arundel: Wasson, ed., REED: Devon, 31-2, 82-4; Somerset, ed., REED: Shropshire, 127-9, 132-3, 135, 147, 159, 164, 174, 180, 182, 187, 189, 354; Louis, ed., REED: Sussex, 14-18, 44, 49, 51-2, 72, 83, 85, 91, 98, 183-6. Oxford: Wasson, ed., REED: Devon, 43, 45, 150, 159-60, 213-14, 217, 229, 235, 281; Somerset, ed., REED: Shropshire, 82, 87, 169, 172, 175; Louis, ed., REED: Sussex, 58, 60, 62-9, 73, 79-81; Elliot, ed., REED: Oxford, 419. 
